\title{
In situ starch degradation of different feeds in the rumen
}

\author{
P Cerneau *, B Michalet-Doreau \\ Station de Recherches sur la Nutrition des Herbivores, Unité de la Valour Alimentaire, \\ CRVZ-INRA de Theix, 63122 Ceyrat, France
}

(Received 10 July 1990; accepted 27 November 1990)

\begin{abstract}
Summary - The in situ starch degradation of 5 feeds (barley, maize, pea, oats and wheat bran) has been measured (trial 1), and the influence of particle size on starch degradation investigated with 3 feeds (barley, maize, pea) (trial 2). The starch degradability of barley, oats and wheat bran was found to be higher than that of pea, and higher again than that of maize: $98,97,96,90$ and $58 \%$ respectively. For barley, oats and wheat bran, starch was degraded more rapidly than the other dry matter $(\mathrm{pm})$ components. Maize and pea starches were degraded at the same rate as non-starchy components. The particle size variations between feeds ground on the same screen may partly explain variations in starch degradability. When the particle size increased from 0.8 to $6.0 \mathrm{~mm}$ screen grinding, in situ starch degradability decreased; the decrease was higher for maize (13.8 points) than for barley (7.4 points) or pea (10.4 points).
\end{abstract}

starch / in situ degradation / particle size / nylon bag technique

Résumé - Étude de la dégradation in situ de l'amidon de différents aliments dans le rumen. La dégradation in situ de l'amidon de 5 aliments (avoine, orge, maïs, son fin de blé) a été mesurée (essai 1), ainsi que l'influence de la taille des particules de l'échantillon pour 3 de ces aliments (orge, maïs, pois) (essai 2). La dégradabilité de l'amidon de l'orge, de l'avoine et du son de blé est plus élevée que celle du pois, qui est elle-même plus élevée que celle du maïs, soit respectivement 98,97 , 96, 90 et 58\%. Par ailleurs la dégradabilité de l'amidon d'orge, et surtout celle de l'avoine et du son de blé, est plus élevée que celle des autres constituants de la matiere sèche. Pour le maïs et le pois, la dégradabilité de l'amidon est égale à celle des constituants non amylacés. Les variations de taille de particules entre aliments broyés à la même grille $(0,8 \mathrm{~mm})$ pourraient expliquer en partie les variations de dégradabilité in situ de l'amidon dans le rumen. Dans lessai 2, l'augmentation de la taille des particules, par le changement de la grille de broyage de 0,8 à $6,0 \mathrm{~mm}$, se traduit par une diminution de la dégradabilité in situ de l'amidon plus importante pour le mais (13,8 points entre les 2 broyages extrêmes), que pour l'orge (7,4 points) ou le pois (10,4 points).

amidon / dégradation in situ / taille des particules / technique des sachets de nylon

\footnotetext{
${ }^{*}$ Correspondence and reprints.
} 


\section{INTRODUCTION}

The energetic value of a diet or a feed depends on organic matter digestion in the rumen and in particular on starch digestion, although this is not the only factor. Ruminal starch digestion depends on the intrinsic characteristics of diet or feed (degradability) and on the intensity and duration of bacterial activity in the rumen (Malestein et al, 1982, 1984; Ørskov, 1986). Starch digestion by ruminants has been reviewed and discussed (Ørskov, 1986; Owens et al, 1986). These reviews underline the importance and the site (ruminal or intestinal) of starch digestion, as well as the influence of the nature of feed and technological processing.

In order to demonstrate the influence of the latter 2 phenomena, the kinetics of in situ starch degradation in the same ruminal conditions were compared for several feeds (trial 1). The second trial was performed to investigate the influence of particle size upon ruminal starch degradation by in situ technique (trial 2).

\section{MATERIAL AND METHODS}

\section{Trial 1}

\section{Feeds}

Starch degradation in 5 feeds was measured: 3 whole and uncooked cereal grains (maize, barley, oats), one cereal by-product (wheat bran) and one legume grain (smooth pea); the chemical characteristics of these are shown in table 1. Nitrogen was determined according to a microKheldahl method ( $N \times 6.25)$, cell wall constituents were analyzed (Van Soest and Wine, 1967) and an amylase was added to improve filtration (Giger and Pochet, 1987). The feeds were ground using a hammer mill with a $0.8-\mathrm{mm}$ sieve, in view of the in situ technique.

\section{In situ technique}

In situ measurements of degradation were carried out using 3 dry Holstein cows fitted with a ruminal cannula. At 08.00 and $17.00 \mathrm{~h}$, they were fed $7 \mathrm{~kg}$ dry matter (DM) per animal per day of hay and concentrate (70:30); the composition of concentrate (percent of dry matter) was: barley (43), sugar-beet pulp (40), soybean meal (10), molasses (5), minerals (2) (MichaletDoreau et al, 1987). After grinding, the foodstuffs were placed in nylon (pore size, $46 \mu \mathrm{m}$ ) bags (internal dimensions $6 \times 11 \mathrm{~cm}$ ), with $3 \mathrm{~g}$ per bag, and a sample mass/area ratio of 20 $\mathrm{mg} / \mathrm{cm}^{2}$. The bags were then placed in the rumen at the same time just before the morning feed, and then removed after $2,4,8,16,24$ or $48 \mathrm{~h}$ of incubation. Six measurements were made for each incubation time ( 3 cows $\times 2$ replications). Following incubation the bags were washed in a washing machine with cold water ( 3 $\times 3 \mathrm{~min}$ ), then dried at $80^{\circ} \mathrm{C}$ and weighed.

The 2 bags for each animal and each point in time were combined to carry out the starch content determination by the enzymatic method (Thivend et al, 1965). After starching, the starch was degraded to glucose by an amyloglucosidase; the glucose thus formed was determined by colorimetry (Trinder, 1969). The foodstuff starch degradation kinetics were described by a single exponential equation (Ørskov and McDonald, 1979), as follows:

$$
D(t)=a+b x\left(1-e^{-c t}\right)
$$

Table I. Chemical composition of feeds.

\begin{tabular}{llllll} 
Feed & \multicolumn{6}{c}{$\begin{array}{c}\% D M \\
\text { Crude } \\
\text { protein }\end{array}$} & & & & \\
\hline & & & & & \\
Barley & 13.4 & 46.2 & 14.0 & 5.1 & 0.7 \\
Maize & 12.6 & 54.8 & 10.1 & 7.2 & 0.7 \\
Oats & 12.1 & 30.1 & 25.1 & 13.5 & 2.4 \\
Pea & 23.9 & 40.5 & 11.9 & 5.5 & 0.6 \\
Wheat bran & 20.1 & 24.9 & 20.5 & 7.4 & 2.0
\end{tabular}

- NDF = neutral detergent fiber; $A D F=$ acid detergent fiber; $A D L=$ acid detergent lignin. 
which implies 3 fractions in the sample: one rapidly degradable fraction (a), one slowly and potentially degradable (b) with a rate reducing exponentially $\left(e^{-c t}\right)$, and one non-degradable (Ind $=100-a-b)$.

Parameter values were obtained by fitting the data, using a non-linear regression procedure based on Marquardt's method (Marquardt, 1963), performed by the NLIN procedure of the statistical analysis system (SAS Institute, 1985). This technique is an iterative curve fitting procedure to reduce the residual sum of squares which is associated with regression model. In order to compare nitrogen degradability of foodstuffs in the rumen, a feed passage rate out of the rumen of 0.06 per $h$ was taken (Vérité et al, 1987 ), and the ruminal degradability of DM and starch calculated by integrating the quantity of DM and starch remaining in the bag with the particle turnover rate (Ørskov and McDonald, 1979) for each time interval:

$$
\operatorname{Deg}=a+b c /(c+0.06)
$$

\section{Statistical analysis}

Variance analysis was performed on data using the general linear model procedure of SAS
(SAS Institute, 1985), with a controlled factor (nature of the feed). Duncan's multiple range test was employed to separate means when significant effects were observed $(P<0.05)$ (Duncan, 1955).

\section{Trial 2}

\section{Feeds}

The influence of particle size in situ starch degradation was investigated; 3 feeds (barley, maize and pea) were ground through either 0.8 , 3.0 or $6.0-\mathrm{mm}$ screens. Foodstuff particle size was determined by wet sieving (Grenet, 1984). Each $10 \mathrm{~g}$ sample was first soaked for $15 \mathrm{~min}$ in water, then sieved for $20 \mathrm{~min}$ in a stream of water using an electromagnetic screener ( 3000 vibrations $/ \mathrm{min}$ ) and 8 sieves, with mesh sizes respectively of $4,2.5,1.6,0.8,0.4,0.25,0.1$ and $0.05 \mathrm{~mm}$. Waste water was filtered (Durieux filter 2B) to recover particles that were insolubilised and $<50 \mathrm{~m}$. Each measurement was carried out in triplicate. Dry matter content was determined for each batch of given particle size thus obtained. The particle size distribution was taken as the percentage distribution of total DM contents found by sieving and filtration (table II).

Table II. Particle size distribution of feeds after grinding (\% of dry matter retained on screens and filter papers).

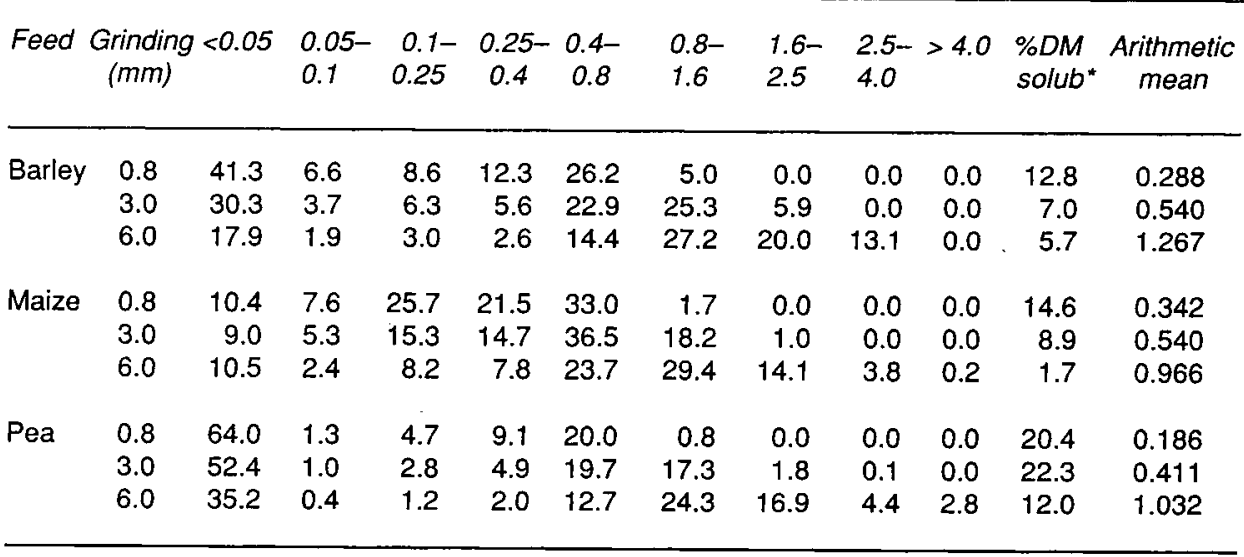

\footnotetext{
• DM solubilized in water.
} 
After grinding the foodstuff particle size was characterized by the arithmetic mean (Israelsen, 1968) calculated from the median of each particle size class indexed to its percentage by weight. In the case of the coarse screen $(4.0 \mathrm{~mm})$, the mean value was taken to be 5.5 $\mathrm{mm}([4+[4-2.5]])$.

\section{In situ technique}

In situ kinetics and parameter values were established with the same experimental procedure and calculations as in trial 1 .

\section{Statistical analysis}

Variance analysis was performed on data using the SAS general linear system procedure (SAS Institute, 1985), by a factorial model with interaction:

$$
Y_{i j}=m_{i j}+F_{i}+G_{j}+F_{i} \cdot G_{j}+e_{i j}
$$

where Yij represented DM or starch degradation (Degradability, a, b, c, Ind), $F_{i}$ and $G_{j}$, the 2 main effects, representing respectively the feed (corn, barley and pea) and the diameter of the grinding sieve $(0.8,3.0$ or $6.0 \mathrm{~mm})$, and $F_{i} \cdot G_{j}$, the crossed effect. Duncan's multiple range test was employed to separate means when a significant effect was observed $(P<0.05)$ (Duncan, 1955).

\section{RESULTS}

\section{Trial 1}

The starches of cereals and cereal byproducts studied were divided into 2 groups according to their degradability: on the one hand, barley, oats, and wheat bran whose degradability reaches $95 \%$, and on the other hand, maize whose starch degradability does not exceed $50 \%$ (table III). Pea degradability is as high $(90 \%)$ but significantly different from that of barley or oats. For barley, oats and wheat bran, $82-95 \%$ starch was degraded very rapidly, whereas this fraction only represented $56 \%$ of pea, and $26 \%$ of maize. The rate of ruminal degradation of the potentially degradable fraction of maize starch was also low: 0.045 vs $0.571 \mathrm{~h}^{-1}$ for barley. Maize starch, as well as that of pea, was degraded in the rumen at the same rate as the non-starchy constituents, and DM degradability was similar to that of the starchy fraction (table III). On the other hand barley starch, and even more so that of oats and wheat bran, were degraded more rapidly than other constituents of the DM feed, the degradability of the starchy fraction being 98,97 and $96 \%$ respectively for barley, oats and wheat bran, while that of dry matter only reached 86,75 and $77 \%$ respectively.

\section{Trial 2}

When particle size increased, starch degradability decreased from 57.8 to $44.0 \%$ when maize was ground through a 0.8 or $6.0-\mathrm{mm}$ screen. For the other feeds, although less important, the difference in starch degradability between the ground samples through the $0.8-\mathrm{mm}$ and those through the $6.0-\mathrm{mm}$ screen was equally significant. The variations were principally a consequence of a decrease in the rapidly degraded fraction, which passed from 26 to $0 \%$ for maize, from 82 to $47 \%$ for barley and from 56 to $28 \%$ for pea (table IV). The degradation rate of potentially degradable starch in the rumen remained constant whatever the particle size of maize and pea, and varied slightly for barley. The decrease in degradability linked to the increase in particle size was significantly more important for the least degraded feeds such as maize (13.8 points) than for the feeds whose degradability is high, like barley ( 7 points). 
Table III. Influence of type of feed on the in situ degradability and the values of parameters of degradation.

\begin{tabular}{|c|c|c|c|c|c|}
\hline \multicolumn{6}{|c|}{ Dry matter } \\
\hline Feed & Degradability & Ind & $a$ & $b$ & $c$ \\
\hline Barley & $82.8^{b}$ & $12.3^{a}$ & $62.5^{\mathrm{a}}$ & $25.2^{\mathrm{ad}}$ & $0.249 a$ \\
\hline Maize & $58.0^{a}$ & $0.0^{\mathrm{b}}$ & $28.2^{b}$ & $71.8^{\mathrm{b}}$ & $0.043^{b}$ \\
\hline Oats & $74.6^{\mathrm{d}}$ & $15.8^{a}$ & $63.6^{a}$ & $20.6^{a}$ & $0.07 \mathrm{~b}$ \\
\hline Pea & $88.6^{c}$ & $0.4^{b}$ & $60.3^{a}$ & $39.3^{c}$ & $0.159^{c}$ \\
\hline Wheat bran & $77.2^{d}$ & $14.9^{a}$ & $51.6^{c}$ & $33.6^{\mathrm{cd}}$ & $0.209^{a c}$ \\
\hline \multicolumn{6}{|c|}{ Starch } \\
\hline Feed & Degradability & Ind & $a$ & $b$ & $c$ \\
\hline Barley & $98.3^{a}$ & $0.0^{a}$ & $82.0^{a}$ & $18.0^{\mathrm{a}}$ & $0.571^{a}$ \\
\hline Corn & $57.8^{\mathrm{b}}$ & $0.0^{a}$ & $26.5^{b}$ & $73.5^{b}$ & $0.045^{b}$ \\
\hline Oats & $97.4^{\mathrm{ca}}$ & $0.0^{a}$ & $94.5^{\mathrm{c}}$ & $5.5^{\mathrm{c}}$ & $0.071^{b}$ \\
\hline Pea & $90.0^{d}$ & $0.0^{\mathrm{a}}$ & $55.9^{d}$ & $44.1^{d}$ & $0.207^{\mathrm{c}}$ \\
\hline Wheat bran & $96.4^{c}$ & $0.3^{a}$ & $82.8^{a}$ & $16.8^{\mathrm{a}}$ & $0.254^{c}$ \\
\hline
\end{tabular}

Different letters in the same column indicate a significative difference $(P<0.05)$.

Table IV. Influence of grinding fineness on the in situ starch degradability and on the parameter values of the starch degradation.

\begin{tabular}{|c|c|c|c|c|c|c|}
\hline \multirow[t]{2}{*}{ Feed } & \multirow{2}{*}{$\begin{array}{l}\text { Grinding } \\
(\mathrm{mm})\end{array}$} & \multirow[t]{2}{*}{ Degradation } & \multicolumn{4}{|c|}{ Degradation parameters } \\
\hline & & & Ind & a & $b$ & $c$ \\
\hline \multirow[t]{3}{*}{ Barley } & 0.8 & $98.3^{a}$ & $0.0^{a}$ & $82.0^{a}$ & $18.0^{a}$ & $0.571^{a}$ \\
\hline & 3.0 & $94.6^{a b}$ & $0.0^{\mathrm{a}}$ & $50.8^{b}$ & $49.2^{b}$ & $0.490^{b}$ \\
\hline & 6.0 & $90.9^{b}$ & $0.4^{a}$ & $46.6^{\mathrm{b}}$ & $53.0^{\circ}$ & $0.304^{c}$ \\
\hline \multirow[t]{3}{*}{ Maize } & 0.8 & $57.8^{a}$ & $0.0^{a}$ & $26.5^{a}$ & $73.5^{a}$ & $0.045^{a}$ \\
\hline & 3.0 & $61.0^{a}$ & $3.3^{\mathrm{b}}$ & $30.5^{a}$ & $66.2^{a}$ & $0.055^{\mathrm{a}}$ \\
\hline & 6.0 & $44.0^{b}$ & $0.7^{a}$ & $0.0^{\mathrm{b}}$ & $99.3^{b}$ & $0.048^{a}$ \\
\hline \multirow{3}{*}{ Pea } & 0.8 & $90.0^{a}$ & $0.0^{\mathrm{a}}$ & $55.9^{a}$ & $44.1^{\mathrm{a}}$ & $0.207^{a}$ \\
\hline & 3.0 & $85.5^{a}$ & $0.0^{\mathrm{a}}$ & $42.8^{b}$ & $57.2^{b}$ & $0.177^{\mathrm{a}}$ \\
\hline & 6.0 & $79.6^{b}$ & $0.0^{a}$ & $28.2^{c}$ & $71.8^{c}$ & $0.152^{a}$ \\
\hline
\end{tabular}

Different letters in the same column indicate a significative difference $(P<0.05)$. 
The influence of grinding fineness on DM degradability or starch degradability was similar. Between the 2 grinding extremes $(0.8$ and $6.0 \mathrm{~mm})$, the degradability differences were 13,5 and 12 points respectively for maize, barley and pea DM and 14,7 and 10 points for starch of the same feeds.

\section{DISCUSSION}

The present experiments have shown large differences in the degradation of starch from different feeds. The in situ starch degradability of barley and oats was higher than that of pea, and higher again than that of maize. These variations in starch degradability between feeds could be due to variations in the percentage of particles escaping through the bag pores and not being degraded. The percentage of fine particles $(<50 \mu \mathrm{m})$ varied from 10.4-41.3 for maize and barley respectively after grinding with a $0.8-\mathrm{mm}$ screen. The particle losses were greater as the percentage of fine particles increased. If the lost particles are digested at the same rate as those in the bag, feed degradability is then overestimated. But this overestimation of DM degradability was almost equal between feeds: 9.0 points for maize and 7.8 points for barley. Nevertheless, the feed particle size variations must explain part of the starch degradability variations between feeds, the finer particles being degraded more rapidly in the rumen. The smaller the particle size, the higher the percentage of maize degraded in vitro (Cone et al, 1989), or the in situ degradability of maize (Galyean et al, 1981) and of sorghum (Figroid et al, 1972) DM.

The difference in in situ degradation between maize and the other cereals is in ac- cordance with the results of HerreraSaldana et al (1988), although the percentage of degraded starch after $2 \mathrm{~h}$ incubation in the rumen was higher in this trial: 28,10 and $95 \%$ respectively of the starch from maize, barley and oats disappeared during the first $2 \mathrm{~h}$ of incubation in this trial against 9,36 and $80 \%$ in the study of Herrera-Saldana et al (1988). The composition of the diet given to the animal could have been the origin of these differences. Indeed, in in vitro degradation measurements, the amylolytic activity in rumen fluid from a concentrate-fed cow is higher than that of a hay-fed cow (Cone et al, 1989), and the increase is greatest for the starch sources with low degradability (Malestein et al, 1988). After $6 \mathrm{~h}$ incubation in rumen fluid, fermentability of pea is lower than that of barley when the animals which give the rumen fluid are fed hay (Malestein et al, 1988). On the contrary, the fermentability of these 2 feeds, like their in situ degradability in this trial, is similar when the animals are fed a diet based on hay and concentrate. So, the ranking of starch degradability from different sources can be modified by the composition of the diet.

In trial 2, the increase in grinding fineness led to an increase in in sacco starch degradability. This result agrees with other results on in situ dry matter or nitrogen degradability (Nordin and Campling, 1976; Weakley et al, 1977; Lindberg, 1981; Freer and Dove, 1984; Nocek, 1985). In this study, the increase of in situ starch degradability with grinding was greater for maize than for barley. The feed particle size was reduced with the increase in grinding fineness, and differences in degradation according to particle size were more important for maize than for wheat and oats (Cone et al, 1989). 


\section{CONCLUSION}

The proportion of starch digested in the rumen (measured as in situ disappearance) or in the small intestine varies between feeds, which could alter the energy value of feeds. Starch digestion in the rumen is accompanied by energy loss in the form of methane and fermentation heat. Furthermore, efficiency of metabolizable energy utilization for both maintenance and production is higher for glucose than for volatile free acids. Consequently, starch escaping from the rumen should improve energetic efficiency of production by ruminants (Owens et al, 1986).

In vivo, increased processing generally increases ruminal digestion of maize starch. Finely ground grains are more extensively digested in the rumen than whole or rolled grains (Owens et al, 1986). Two factors act in an opposite manner. When grains are ground, potential digestion of starch grains increases, but the passage rate of grains through the rumen is accelerated and ruminal digestion time is reduced. In in situ measurements, only potential starch digestion is studied.

\section{ACKNOWLEDGMENTS}

Our thanks go to $M$ Dudilieu and $P$ Journaix for the carrying out the quantitative starch analysis, and those of the bag residues. Gratitude is expressed to $\mathrm{J}$ Aufrere for the references and $P$ Cooks for translating the manuscript into English.

\section{REFERENCES}

Cone JW, Cline-Theil W, Malestein A, Van'T Klooster A (1989) Degradation of starch by incubation with rumen fluid. A comparison of different starch sources. J Sci Food Agric 49, 173-183
Duncan DB (1955) Multiple range and multiple $F$ test. Biometrics 1, 4

Figroid W, Hale WT, Theurer CB (1972) An evaluation of the nylon bag technique for estimating rumen utilization of grains. J Anim Sci 35, 112-120

Freer M, Dove H (1984) Rumen degradation of protein in sunflower meal, rapeseed meal and lupin seed, using nylon bags. Anim Feed Sci Technol 11, 87-101

Galyean ML, Wagner DG, Owens FN (1981) Dry matter and starch disappearance of corn and sorghum as influenced by particle size and processing. J Dairy Sci 64, 1804-1812

Giger S, Pochet S (1987) Méthodes d'estimation des constituants pariétaux dans les aliments destinés aux ruminants. Bull Tech CRVZ Theix INRA 70, 49-60

Grenet E (1984) Wet sieving technique for estimating particle size in the herbivore digesta. In: Techniques in Particle Size Analysis of Food and Digesta in Ruminants (Kennedy PM, ed) Proc Workshop, 7-8th Sep 1984, Banff, Canada. Can Soc Anim Sci Occ publ 1, 167-168

Herrera-Saldana R, Huber JF, Poore MH (1988) In vitro and in situ dry matter, crude protein and starch degradability of five cereal grains. J Dairy Sci 71 (suppl 1) 177

Israelsen M (1968) Determination of particle size in wafers and pellets of dried forages. Bioteknik Inst Rep, Kolding

Lindberg JE (1981) The effect of sample size and sample structure on the degradation of dry matter, nitrogen and cell walls in nylon bags. Swedish J Agric Res 11, 71-76

Malestein A, Van'T Klooster AT, Counotte GHM, Prins RA (1982) Concentrate feeding and ruminal fermentation. II. Influence of concentrate ingredients on $\mathrm{pH}$ and on L-lactate concentration in incubations in vitro with rumen fluid. Neth J Agric Sci 30, 259-273

Malestein A, Van'T Klooster AT, Counotte GHM (1984) Concentrate feeding and ruminal fermentation. 3. Influence of concentrate ingredients on $\mathrm{pH}$, on DL-lactic acid concentration in rumen fluid of dairy cows on dry matter intake. Neth J Agric Sci 32, 9-21

Malestein A, Van'T Klooster AT, Cone JW (1988) Degradability of various types of starch by incubation with rumen fluid or with bacterial amylase. Z Tierphysiol Tierenähr Futtermittelk 59, 225-232 
Marquardt W (1963) An algorithm for least squares estimation of nonlinear parameters. Soc Ind Appl Math 11, 431

Michalet-Doreau $B$, Vérité $R$, Chapoutot $P$ (1987) Méthodologie de mesure de la dégradabilité in sacco de l'azote des aliments. Bull Tech CRVZ Theix INRA 69, 5-7

Nocek JE (1985) Evaluation of specific variables affecting in situ estimates of ruminal dry matter and protein digestion. $J$ Anim Sci $60,1347-1358$

Nordin M, Campling RC (1976) Digestibility studies with cows given whole and rolled cereal grains. Anim Prod 23, 305-315

Ørskov ER (1986) Starch digestion and utilization in ruminants. J Anim Sci 63, 1624-1633

Ørskov ER, Mc Donald J (1979) The estimation of protein degradability in the rumen from incubation measurements weighted according to rate of passage. J Agric Sci (Camb) 92, 499-503

Owens FN, Zinn RA, Kim YK (1986) Limits to starch digestion in the ruminants small intestine. J Anim Sci 63, 1634-1648
SAS Statistical Analysis System Institute (1985) SAS User's Guide: Statistics. SAS Institute Inc, Cary, NC, USA, 1035

Thivend P, Mercier C, Guilbot A (1965) Dosage de l'amidon dans les milieux complexes. Ann Biol Anim Biochim Biophys 5, 513-526

Trinder $P$ (1969) Determination of blood glucose using an oxydase peroxydase system with a non-carcinogenic chromogen. $J$ Clin Pathol 22, 158-161

Van Soest PJ, Wine RH (1967) Use of detergents in the analysis of fibrous feeds. Determination of plant cell-wall constituents. J Assoc Off Agric Chem 50, 50-55

Vérité R, Michalet-Doreau B, Chapoutot P, Peyraud JL, Poncet C (1987) Révision du système des protéines digestibles dans I'intestin (PDI). Bull Techn CRVZ Theix INRA 70, 19-34

Weakley DC, Owens FN, Heath DG, Shockey BJ (1977) Particle size and soybean meal value for ruminants. J Anim Sci 45 (suppl 1), 268 